\section{Mulch Effects on Floral Resources and Fruit Production of Squash, and on Pollination and Nesting by Squash Bees}

\author{
Caitlin E. Splawski ${ }^{1,3}$, Emilie E. Regnier ${ }^{1}$, S. Kent Harrison ${ }^{1}$, \\ Karen Goodell ${ }^{2}$, Mark A. Bennett $^{1}$, and James D. Metzger ${ }^{1}$
}

Additional index words. Cucurbita pepo, paper mulch, Peponapis pruinosa, pollination

Summary. Zucchini squash (Cucurbita pepo) has a high pollination demand, and the native, ground-nesting squash bee (Peponapis pruinosa) provides the majority of the crop's pollination requirement in some environments. Squash bees nest directly in crop fields, and nests can be disturbed by tillage and other management operations. Mulches that use municipal waste materials may provide a weed control strategy for squash plantings that is more benign to squash bees than cultivation. Field and greenhouse studies were conducted in 2011 and 2012 to compare the effects of nontillage weed control methods including polyethylene black plastic, woodchips, shredded newspaper, a combination of shredded newspaper plus grass clippings (NP + grass), and bare soil (control) on soil characteristics, squash pollination and fruit production, and squash bee nesting. Woodchips, shredded newspaper, and $\mathrm{NP}+$ grass mulch decreased soil temperature, while soils beneath newspaper mulch retained more moisture. Unmarketable, misshapen fruit occurred more frequently in plastic than in the other mulch treatments. No measurable differences in floral resource production or crop pollination were found among treatments, suggesting that misshapen fruit resulted from high soil temperatures in black plastic plots rather than poor pollinator attraction. Squash bee nests were located within bare soil, newspaper, and NP + grass plots, indicating that these mulches did not prevent nesting. NP + grass mulch had a positive effect on plant growth and fruit production, possibly from an addition of plant-available nitrogen or the presence of preferable nesting ground. Shredded newspaper when combined with grass clippings performed as an effective mulch material that improved crop performance with no apparent negative impacts on squash bee nesting or on squash floral resources and pollination.

S oil tillage is the most energy consuming of all agricultural field operations (Chauhan et al., 2012). In addition to monetary and environmental cost of fossil fuels, the time and labor required for tillage are also significant factors for farmers to consider. Herbicides reduce the need for

This project was funded by the USDA North Central Integrated Pest Management (NCIPM) program.

Salaries and additional research support were provided by state and federal funds appropriated to the Ohio Agricultural Research and Development Center, Ohio State University journal article no. HCS 13-06.

We thank Kelly Keith at the Newark Advocate for providing newspaper, and Mid Ohio Shredding and Ohio Mobile Shredding for shredding the newspaper. Thanks to Brett Tanner, Weston Applefeller, and the Columbus Crew for providing grass clippings.

This paper is a portion of a thesis submitted by Caitlin Splawski in partial fulfillment of a Master of Science degree from The Ohio State University.

${ }^{1}$ Department of Horticulture and Crop Science, The Ohio State University, 202 Kottman Hall, 2021 Coffey Road, Columbus, $\mathrm{OH} 43210$

${ }^{2}$ Department of Evolution, Ecology and Organismal Biology, The Ohio State University, 2054 Founders Hall, 1179 University Drive, Newark, OH 43055

${ }^{3}$ Corresponding author. E-mail: csplawski@gmail.com. tillage (Gianessi and Reigner, 2007), but can lead to herbicide resistance in weeds and unintended effects on beneficial organisms (Liebman, 2001; Powles and $\mathrm{Yu}, 2010$ ).

There has been recent interest in alternative weed control practices for organic growers who rely heavily on mechanical cultivation, timely hand weeding, or both. Organic and conventional growers may value an alternative to mechanical cultivation since tillage can increase soil erosion, degrades soil structure and microbial communities, and releases sequestered carbon dioxide back into the atmosphere (Gianessi and Reigner, 2007; Hobbs et al., 2008). Concerns that the overuse of tillage or herbicides may have negative impacts on human health and ecological integrity, plus increased time and labor costs for growers, indicate a need for weed control practices that mitigate these effects while still maximizing yield (Liebman, 2001).

Mulching can control weeds in fruit and vegetable crops with the added benefit that it limits the need for tillage and exposure of beneficial insects to potentially harmful pesticides. A wide variety of mulch materials have been studied, including plastic film, wood fiber, paper, and living or dead plant material. Many novel mulch materials remain to be investigated with regard to their ability to suppress weeds and improve crop yields. The effects of novel mulches on crop pollinators should also be studied to ensure their overall positive effect on crop management.

Although crop pollinators in general may benefit from reductions in herbicide use and tillage operations, pollinators that use agricultural fields for nesting deserve consideration. One such pollinator is the squash bee, a major pollinator of squash, pumpkins, and gourds (Cucurbita sp.). It is a solitary, ground-nesting species that produces one generation per year (Williams et al., 2009). The females make one or more nests per season where eggs

\begin{tabular}{|c|c|c|c|}
\hline \multicolumn{4}{|l|}{ Units } \\
\hline \multicolumn{4}{|l|}{$\begin{array}{l}\text { To convert U } \\
\text { multiply by }\end{array}$} \\
\hline 1 & $\%$ & $\mathrm{~g} / 100 \mathrm{~g}$ & 1 \\
\hline 29,574 & $\mathrm{fl} \mathrm{oz}$ & $\mu \mathrm{L}$ & $3.3814 \times 10^{-5}$ \\
\hline 29.5735 & $\mathrm{floz}$ & $\mathrm{mL}$ & 0.0338 \\
\hline 0.3048 & $\mathrm{ft}$ & $\mathrm{m}$ & 3.2808 \\
\hline 28.3168 & $\mathrm{ft}^{3}$ & $\mathrm{dm}^{3}$ & 0.0353 \\
\hline 3.7854 & gal & $\mathrm{L}$ & 0.2642 \\
\hline 2.54 & inch $(\mathrm{es})$ & $\mathrm{cm}$ & 0.3937 \\
\hline 25.4 & inch(es) & $\mathrm{mm}$ & 0.0394 \\
\hline $1.6387 \times 10^{4}$ & inch $^{3}$ & $\mathrm{~mm}^{3}$ & $6.1024 \times 10^{-5}$ \\
\hline 1.1209 & $\mathrm{lb} / \mathrm{acre}$ & $\mathrm{kg} \cdot \mathrm{ha}^{-1}$ & 0.8922 \\
\hline 0.0254 & mil & $\mathrm{mm}$ & 39.3701 \\
\hline 28.3495 & $\mathrm{oz}$ & g & 0.0353 \\
\hline 1 & $\mathrm{ppm}$ & $\mathrm{mg} \cdot \mathrm{L}^{-1}$ & 1 \\
\hline 2.2417 & ton $(\mathrm{s}) /$ acre & $\mathrm{Mg} \cdot \mathrm{ha}^{-1}$ & 0.4461 \\
\hline$\left({ }^{\circ} \mathrm{F}-32\right) \div 1.8$ & ${ }^{\circ} \mathrm{F}$ & ${ }^{\circ} \mathrm{C}$ & $\left({ }^{\circ} \mathrm{C} \times 1.8\right)+32$ \\
\hline
\end{tabular}


are deposited and provisioned solely with squash pollen. Males and females forage on nectar and pollen, and females tend to nest directly under the squash plants from which they forage (Roulston and Goodell, 2011). Female squash flowers must be visited a minimum of seven times for optimum seed set and fruit development, depending on the crop cultivar and bee species (Julier and Roulston, 2009; Walters and Taylor, 2006). Each flower is open for $\mathrm{ld}$, from about sunrise until noon (Nepi et al., 1996; Tepedino, 1981).

Farms with consistent management practices provide good study environments for oligolectic (specialist) bee species since current generations of bees have developed from the resources that were available to the previous generation (Roulston and Goodell, 2011). For example, weed management strategies used within squash fields could directly or indirectly impact the population of squash bees present. A decrease in the abundance of squash bees may limit pollen transfer needed for fruit production since squash has a relatively high pollination demand (Julier and Roulston, 2009; Walters and Taylor, 2006). Insufficient wild pollinators could also raise production costs for growers if honeybee (Apis mellifera) colonies need to be purchased during the relatively long squash-flowering season.

Squash bees are expected to show high sensitivity to insecticide application and tillage because they nest within squash fields and have no noncrop host plants in most of their range (Hurd et al., 1974). Squash bees place the greatest density of their brood cells 16 to $30 \mathrm{~cm}$ under the soil surface (Mathewson, 1968), which overlaps with some tillage depths. The survival and abundance of native pollinators depends in part upon the availability of food and nesting resources within foraging range. Herbicide application may indirectly harm bees by reducing floral abundance and foraging resources on farms (Holzschuh et al., 2008). Although squash bees collect pollen exclusively from squash, it has been known to collect nectar from other floral hosts (K. Goodell, unpublished data).

The use of mulch for weed control could alleviate some incidental risks posed to pollinators by herbicides and tillage, but could also alter important aspects of pollinator habitat with negative consequences for squash bee populations and crop pollination. Mulch applied to the soil surface acts as a physical barrier to weed emergence and could similarly prevent bee nesting. Squash bees prefer irrigated soils that are low in clay content (Roulston and Goodell, 2011). The way in which mulch alters the soil microclimate may positively or negatively influence nest site preference or larval development (Roulston and Goodell, 2011).

Mulches may also affect resource allocation patterns of plants that influence fruit development and the production of floral resources, such as nectar and pollen. Nectar quantity and composition vary widely due to environmental factors such as temperature, soil moisture, and humidity (Cruden et al., 1983; Fahn, 1979; Wyatt et al., 1992). In addition, mulches that immobilize nitrogen because of a high carbon to nitrogen ratio may influence the quality (e.g., protein and sugar content) of the floral resources produced and thus pollinator visitation and crop pollination.

The objective of this research was to determine the effect of mulch materials on floral resource production, pollination, and fruit set of zucchini, as well as the potential for nesting by its specialist pollinator, the squash bee. Specifically, we tested the following hypotheses: 1) particulate mulch materials will decrease soil temperature fluctuation and increase soil moisture levels in comparison with black plastic and bare soil; 2) particulate mulches will be suitable areas for squash bees to nest, whereas black plastic sheet mulch will prohibit squash bees from nesting; 3 ) mulches that increase soil moisture will increase the quantity and quality of nectar and pollen produced; and 4) mulches that reduce pollen and nectar abundance and quality will reduce pollination of flowers and be associated with aborted or misshapen, poor quality fruit. We tested these hypotheses by investigating mulch effects on soil moisture and temperature, crop plant growth, floral resource production, pollination and fruit set, and squash bee nesting.

\section{Materials and methods}

Mulch MATERIALs. Black plastic film, woodchips, shredded newspaper, and a combination of newspaper and grass clippings (NP + grass). Black, 1.25-mil-thick polyethylene plastic film (Hummert International, Earth City, MO) was used as the plastic mulch. The composted woodchip treatment comprised of mixed hardwood species, and recycled newspaper printed with soy-based ink was obtained from a local newspaper printing facility. It was then shredded into strips $1.6 \mathrm{~cm}$ wide and $30 \mathrm{~cm}$ long and baled for transportation by a document shredding company. Fresh grass clippings were obtained from a local athletic field and consisted of a mixture of kentucky bluegrass (Poa pratensis) and perennial ryegrass (Lolium perenne). The NP + grass treatment consisted of a $2: 1(\mathrm{v} / \mathrm{v})$ ratio of shredded newspaper:grass clippings ( $<7 \mathrm{~d}$ old $)$ applied immediately to the plots.

Crop pollination AND beE NESTING FIELD STUDY. To examine crop pollination and squash bee nesting, each year field experiments were conducted inside one mesh screen enclosure (hereafter, screenhouse) in 2011 at The Ohio State University Waterman Agricultural and Natural Resources Laboratory (WANRL) in Columbus (lat. $40.00^{\circ} \mathrm{N}$, long. $83.02^{\circ} \mathrm{W}$ ) and in 2012 at The Ohio State University, Newark campus in Newark (lat. $40.06^{\circ} \mathrm{N}$, long. $\left.82.40^{\circ} \mathrm{W}\right)$. Screenhouses measured $20 \times 20 \times 7 \mathrm{ft}$ in 2011 and $30 \times 15 \times$ $20 \mathrm{ft}$ in 2012 . Because of high bee mortality in 2011 , a larger screenhouse was used for experiments conducted in 2012.

Soil types were a Crosby silt loam soil (fine, mixed, mesic Aeric Ochraqualfs) at WANRL and a Glenford silt loam soil (fine-silty, mixed, superactive, mesic Aquic Hapludalfs) at the Newark site. The WANRL site had been previously cropped in winter squash and was sprayed with glyphosate at $2.5 \mathrm{lb} /$ acre with $2 \%(\mathrm{v} / \mathrm{v})$ ammonium sulfate before and after tillage to clear the field of weeds before mulches were applied. The raised beds at the Newark site had been previously cropped in native wildflowers. The raised beds were weeded by handpulling plants and lightly hoeing the soil to achieve a level seed bed.

The zucchini cultivar Dunja, a 45-d medium vigor cultivar with intermediate resistance to powdery mildew (Podosphaera fusca) and resistance to watermelon mosaic virus, zucchini yellow mosaic virus, and papaya ringspot virus, was used for both 
experiments. Plants were started in the greenhouse and 3 -week-old seedlings were hand-transplanted into plots after being hardened off under shadecloth. No pest or disease management was used inside the screenhouses. Two-week-old zucchini seedlings were fertilized with $20 \mathrm{~N}-4.4 \mathrm{P}-16.6 \mathrm{~K}$ at a rate of $50 \mathrm{lb} /$ acre. Three-week-old seedlings were fertilized with $9 \mathrm{~N}-$ $19.6 \mathrm{P}-12.5 \mathrm{~K}$ at a rate of $200 \mathrm{ppm}$ at transplanting. Plants were sidedressed 3 weeks after transplanting with $20 \mathrm{~N}-4.4 \mathrm{P}-16.6 \mathrm{~K}$ at a rate of $30 \mathrm{lb} /$ acre when they began to bloom. Overhead irrigation was provided as needed during both years of the study.

Treatments were replicated seven (2011) and eight times (2012) and arranged in a completely randomized design (2011) or in a randomized complete block design (2012). Plot dimensions were $3 \times 3 \mathrm{ft}$ in 2011 and $2 \times 4 \mathrm{ft}$ in 2012 with each plot containing one zucchini plant. We added 30 potted zucchini plants placed around the inside perimeter of the screenhouse in 2012 to supply supplemental nectar and pollen resources. Squash bees were caught by hand from nearby squash fields and introduced into the screenhouses over a period of several weeks beginning mid-June and ending mid-July. In 2011, a total of 50 female and 13 male squash bees were introduced into the screenhouse by 13 July. In 2012, 35 females and five males were introduced into the screenhouse by 6 July. Because of minor bee mortality observed in the screenhouse, additional six female and five male bees were introduced on 3 Aug. 2012. No other pollinators were observed inside the screenhouses during 2011 or 2012

Mulch application and zucchini planting dates were 14 June 2011 and 11 June 2012. In both years, a bare soil, unmulched treatment served as a control. Control plots were left bare and weeds were permitted to grow in 2011 , but were pulled by hand in 2012 to make locating nests easier. Woodchip, newspaper, and NP + grass mulches were applied to the soil surface at a thickness of $5 \mathrm{~cm}$, which corresponded to application rates of $150 \mathrm{Mg} \cdot \mathrm{ha}^{-1}$ for the woodchips, $55 \mathrm{Mg} \cdot \mathrm{ha}^{-1}$ for the shredded newspaper, and $50 \mathrm{Mg} \cdot \mathrm{ha}^{-1}$ for the NP + grass mulch. The newspaper and NP + grass treatments were mixed in plastic buckets with holes drilled in the bottom. About $20 \mathrm{~L}$ of water was applied to the mulch materials and then mixed by hand into a slurry until most of the water had drained from the buckets. The mixed materials were then applied wet to the soil surface. This process was carried out in an attempt to achieve some degree of hydroentanglement, which is a procedure used to bind fibers (Rawal et al., 2007; Xiang and Kuznetsov, 2008). In a preliminary study using shredded newspaper combined with various plant residues, this process improved the strength and integrity of the mulch (Splawski, 2012).

Weekly soil temperature and moisture measurements were taken in each plot at solar noon from June (2012) or July (2011) through August in both years. One reading per plot per week was taken for both soil temperature and moisture. Soil temperature was measured using a soil thermometer and volumetric soil water content was measured using a portable impedance probe (Theta Probe type ML2x; Delta-T Devices, Cambridge, England). The thermometer and moisture probes were inserted beneath the mulch materials to a soil depth of $10 \mathrm{~cm}$. Additionally, precipitation and air temperature data were collected from weather stations located near the study sites.

To determine the effects of mulches on plant growth, we measured plant height and canopy width on 26 July and 18 Aug. 2011, and on 27 June, 13 July, and 22 Aug. 2012. Plant volumes were calculated from these measurements. Relative differences in leaf chlorophyll content were estimated using a handheld chlorophyll meter (Minolta SPAD-502 Plus; Spectrum Technologies, Plainfield, IL) in 2012. Chlorophyll meter readings were taken on 16 July and 22 Aug. 2012 by taking an average of three readings each on a young leaf close to the apical meristem of the plant, a middle-aged leaf, and an older leaf near the base of the plant.

Bee nesting activity was measured during the 2012 season by observing plots within the screenhouses during the morning when bee activity is greatest for $5 \mathrm{~min}$ per replicate block every $3 \mathrm{~d}$ from midJuly to late August. Soil beneath and around the zucchini plants in each block was examined and when a bee was spotted landing on the ground surface, it was tracked until it entered its nest. The nest was then marked with a flag and mapped.

To assess crop pollination, measurements were taken on total fruit production, fruit diameter, and fruit shape. Open female flowers were marked with tape around the pedicel during mornings $3 \mathrm{~d}$ per week and 5 d later fruit were counted, diameter was measured, and fruit shape was determined. Flower and fruit number were recorded throughout the growing season until total flower/fruit production had slowed to less than five flowers/fruit per day. Fruit diameter is highly correlated with fruit weight and seed set, which, in turn, is correlated with the number of ovules that have been pollinated successfully (Cane et al., 2011). To estimate fruit pollination, zucchini diameters were measured using digital calipers placed $8 \mathrm{~cm}$ from the stigmatic end of the fruit $5 \mathrm{~d}$ after bloom from July through August. A fruit yield index (FYI) was calculated (FYI $=$ fruit number $\times$ fruit diameter) to take into account both fruit number and diameter. Misshapen and small aborted fruit occur due to inadequate pollination and are not marketable (Delaplane and Mayer, 2000). Fruit shape was categorized as normal, misshapen (either bulbous or shrunken end), or aborted (Fig. 1).

Floral resource greenhouse AND FIELD STUDIES. The effect of mulches on squash pollen and nectar production was investigated in a greenhouse and field study. The greenhouse experiment was conducted from Jan. through Apr. 2012 at The Ohio State University Kottman Hall greenhouse. The zucchini cultivar Raven, a suitable cultivar for greenhouse production (Shaw and Cantliffe, 2005), was seeded on 23 Jan., and 5-week-old seedlings were transplanted into 3-gal polyethylene nursery pots $25 \mathrm{~cm}$ in height and $25 \mathrm{~cm}$ in diameter on 23 Feb. 2012. The pots were mulched with one sheet of black polyethylene plastic, a 5-cm-thick layer of shredded newspaper, or left bare. A mixture of $85 \%$ pine bark, $10 \%$ composted sewage sludge, and $5 \%$ pea gravel was used as the potting medium. The treatments were replicated 10 times and arranged in a randomized complete block design with one pot containing 

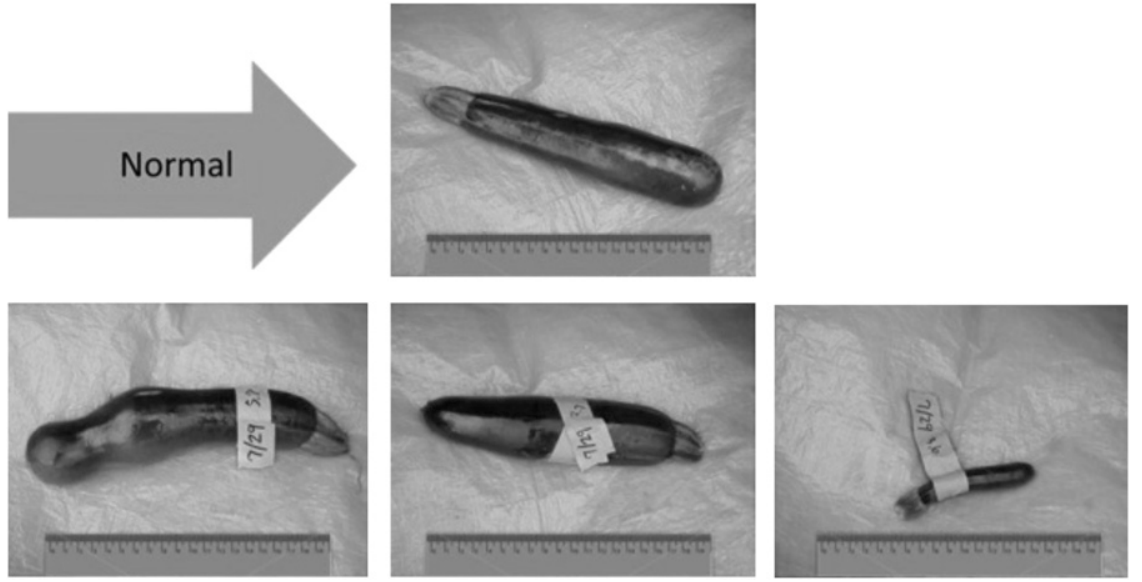

Fig. 1. Images depicting fruit shape categories for zucchini squash with a centimeter ruler: (Top) normal fruit shape; (Bottom) left to right, bulbous misshapen fruit, shrunken-end misshapen fruit, aborted fruit; $1 \mathrm{~cm}=0.3937$ inch.

one of the three mulch treatments and one zucchini plant. The pots were fertigated with $20 \mathrm{~N}-4.4 \mathrm{P}-16.6 \mathrm{~K}$ at 200 ppm using in-pot emitters for 2 min per day. Supplemental lighting was used to expose the zucchinis to a 14-h photoperiod.

Daily flower production was measured from 13 Mar. to 28 Apr. 2012. Pollen was collected predawn by removing the anthers with scissors and suspending them in vials containing $5 \mathrm{~mL}$ of $70 \%$ ethanol. The samples were sonicated for $2 \mathrm{~min}$ and anthers were then rinsed with an additional $5 \mathrm{~mL}$ of $70 \%$ ethanol to dislodge any remaining pollen grains. Anthers were then discarded. After letting pollen settle to the bottom of the vials, $8 \mathrm{~mL}$ of ethanol were removed using a micropipette and $5 \mathrm{~mL}$ of glycerol were added to suspend pollen evenly in solution for counting. Four $20-\mu \mathrm{L}$ subsamples of each replicate were counted using a hemacytometer at $4 \times$ magnification (Das Gracas Vidal et al., 2006; Roulston et al., 2000). Nectar was collected from female flowers between 0900 and $1030 \mathrm{HR}$. Nectar was sampled by removing all available nectar with a volumetric Hamilton syringe inserted into the nectary. Nectar volume was determined by reading the volume collected in the syringe to the nearest $0.5 \mu \mathrm{L}$.

The field study was conducted at WANRL in 2012. Samples were collected from pumpkin cultivar Cannonball grown in a separate field experiment comparing the same mulch treatments and arranged in a randomized complete block design with four replicates. Plot size was $4 \times 30 \mathrm{ft}$ with 10 pumpkin plants per plot. Three pollen samples and one nectar sample were collected per week from four randomly selected flowers on randomly selected plants within each plot consisting of 10 pumpkin plants. Pollen samples were collected between 0500 and 0600 HR before bees had begun to forage for the day.

Nectar was collected from male flowers that were bagged with white, breathable fabric bouffant caps (Cellucap, Philadelphia, PA) secured around the base of the flower predawn to exclude visitation by pollinators and prevent removal of nectar. Nectar was collected only from male flowers to not skew harvest data also collected from this experiment (Splawski, 2012). Samples were collected between 1100 $\mathrm{HR}$ and noon to allow for maximum nectar accumulation (Nepi et al., 2001). Samples were taken in the same manner as in the greenhouse experiment; however, the nectar collected was expelled from the Hamilton syringe onto a digital refractometer (model PAL-1; ATAGO USA, Bellevue, WA) to estimate total sugar content of the sample. Sugar concentration was measured as a soluble solids concentration, which is the number of grams of sucrose per $100 \mathrm{~g}$ solution (Corbet, 2003).

Statistical analyses. Data for the crop pollination and bee nesting field experiments conducted in 2011 and 2012 were analyzed separately due to different experimental designs between years. Data were also analyzed separately for the 2012 floral resource greenhouse and field experiments. For both studies, all data were subjected to analysis of variance (ANOVA) using the PROC GLM procedure for a completely randomized design (2011 crop pollination field experiment) and the PROC MIXED procedure in SAS for a randomized complete block design (all 2012 field and greenhouse experiments) with blocks as a random effect and treatment as a fixed effect (SAS version 9.3 for Windows; SAS Institute, Cary, NC). Plot within sampling date was designated as a random effect and plot was also designated as the subject for a repeated-measures ANOVA of the soil temperature and moisture data. Unstructured covariance was specified in the model. Differences among least squares treatment means were determined using pairwise $t$ tests implemented by the PDIFF option with a comparisonwise error rate of alpha $=0.05$ (Littell et al., 2006). When the PROC GLM procedure was used, treatment means were compared for significant differences according to Fisher's least significant difference test. Means and standard errors presented in tables were generated using the PROC MEANS procedure. Linear regression analyses were performed on treatment means (Gomez and Gomez, 1984) using SigmaPlot version 12.0 (Systat Software, San Jose, CA) to determine the effect of plant volume on fruit yield.

\section{Results}

SOIL MOISTURE AND TEMPERATURE. Weather conditions between 2011 and 2012 were different, with precipitation totaling $30 \mathrm{~cm}$ from June through August in 2011 and only $16 \mathrm{~cm}$ during the same period in 2012 (Fig. 2). The 30-year average precipitation during the June to August period for the experimental site is $33 \mathrm{~cm}$. During the 2011 field season, no irrigation was needed; however, in 2012 , plots were irrigated every $3 \mathrm{~d}$ during the early part of the season to prevent excessive crop water stress.

Soil moisture differed among treatments, but also differed between years. In 2011, volumetric soil water content was lowest under black plastic and greatest under newspaper $(F=15.86 ; \mathrm{df}=4$, 120; $P<0.001$ ) (Table 1). There were no differences in soil moisture among the woodchips, NP + grass, 

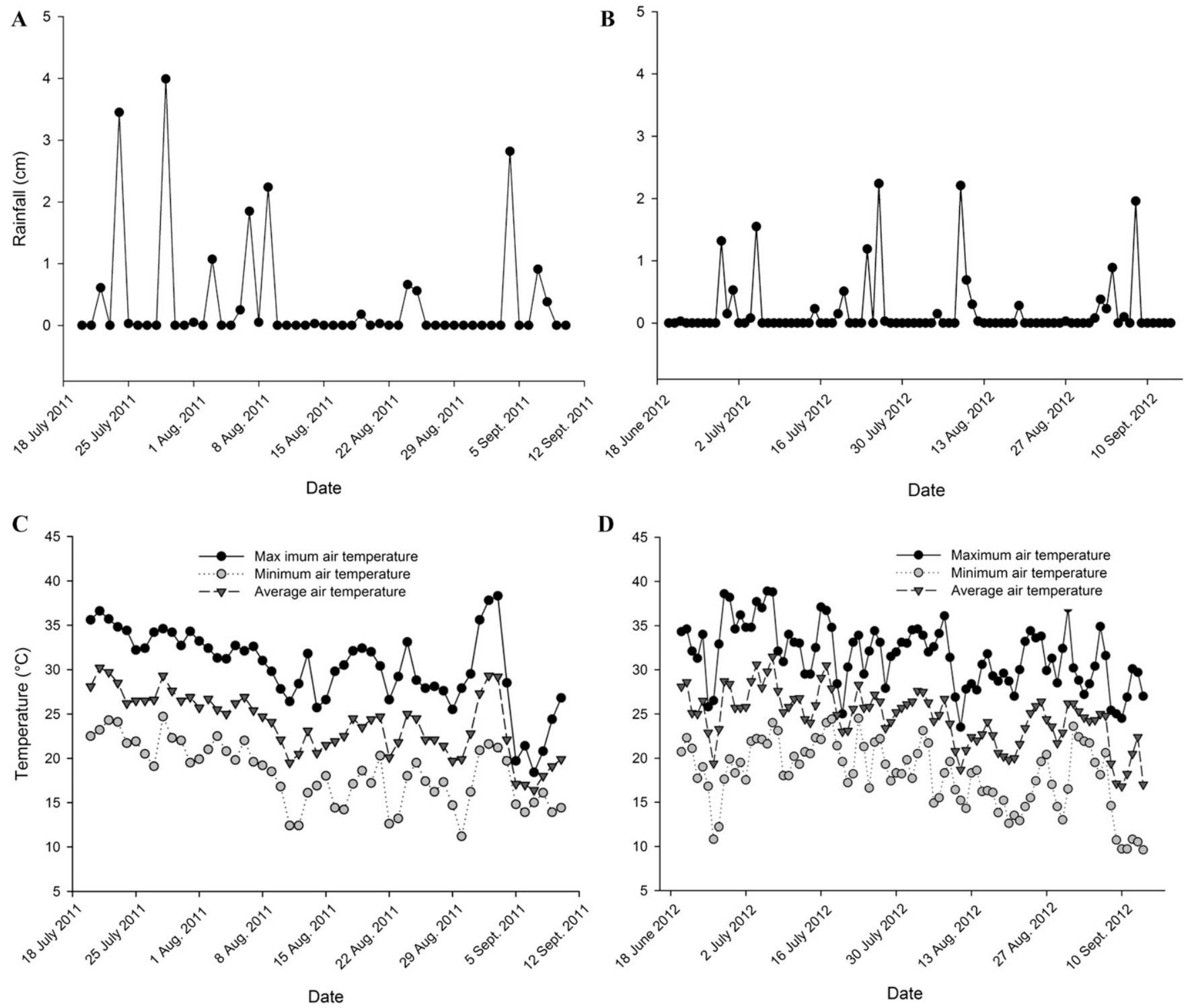

Fig. 2. Ohio Agricultural Research and Development Center weather station data from Columbus, $\mathrm{OH}$, for the 2011 and 2012 growing seasons: (A) daily precipitation from July through Sept. 2011, (B) daily precipitation from June through Sept. 2012, (C) daily maximum, minimum, and average air temperature from July through Sept. 2011, and (D) daily maximum, minimum, and average air temperature from June through Sept. $2012 ; 1 \mathrm{~cm}=0.3937 \mathrm{inch},\left(1.8 \times{ }^{\circ} \mathrm{C}\right)+32={ }^{\circ} \mathrm{F}$.

and bare soil treatments. In 2012, the bare soil treatment had the lowest water content. Plastic and woodchip treatments had slightly greater volumetric soil water content than bare soil, but did not differ from each other. Soil moisture was greatest in the newspaper and NP + grass treatments $(F=23.25 ; \mathrm{df}=4,252 ; P<$ $0.001)$ (Table 1).

Soil temperature also differed among treatments and between years. In 2011 , there was a date by treatment interaction. Plots with plastic mulch had the highest average soil temperatures, followed by bare soil and the NP + grass treatments, and finally by woodchips and newspaper $(F=3.08 ; \mathrm{df}=16,120 ; P<0.001)$

(Fig. 3). There was a difference of $\approx 2{ }^{\circ} \mathrm{C}$ between newspaper and plastic on some dates. In 2012, there was also a date by treatment interaction, but across all dates, the plastic and bare soil treatments had the highest soil temperatures $(F=3.73$; $\mathrm{df}=36$, 280; $P<0.001)$ (Fig. 3). Woodchips, newspaper, and NP + grass maintained similar, lower soil temperatures.

Plant growth. Plant volume differed among treatments and between years. In 2011 , zucchini plants in plastic, NP + grass, and bare treatments produced the largest average plant volume and plants in woodchip and newspaper produced the lowest volumes $(F=4.50 ; \mathrm{df}=4,38 ; P<$ 0.05 ) (Table 2). In 2012, NP + grass plots produced the largest plant volumes, followed by plastic $(F=6.47$; $\mathrm{df}=4,97 ; P<0.001)($ Table 2$)$. Bare, newspaper, and woodchips mulches resulted in the smallest plants. Patterns among treatments were similar earlier and later in the season, although differences were more pronounced early in the season during both years (Table 2 ).

In 2012, SPAD meter readings indicated that plants grown in the $\mathrm{NP}+$ grass, bare, and plastic plots were 
darker green in color than the woodchip or newspaper treatments $(F=5.46$; df $=4,62 ; P<0.001)$, suggesting higher leaf chlorophyll content and higher nitrogen acquisition by the plants. There was a significant linear regression of plant volume on SPAD values $\left(\mathrm{y}=0.02 \mathrm{x}+34.90 ; r^{2}=0.75\right)$, suggesting that SPAD values were positively correlated with greater net photosynthesis and crop growth.

BeE nesting. Because of high bee mortality in 2011, no squash bee nests were located at the WANRL screenhouse in Columbus, OH. In 2012 , bee activity and survival were greater at the larger screenhouse in Newark, OH. There was a total of four confirmed squash bee nests located within the Newark screenhouse. Two of the nests were located within a bare plot, another in a newspaper plot, and the fourth was in a NP + grass plot (Fig. 5A). There were insufficient data to conduct a statistical analysis on nesting site preference; however, these qualitative results suggest that the newspaper and NP + grass mulches do not prevent squash bee nesting.

POLlination AND FRUit PRODUCTION. In 2011, there were no differences in total fruit number among mulch treatments. However, in 2012, plants grown in plastic and $\mathrm{NP}+$ grass plots produced more zucchini fruit than those in newspaper alone, woodchips, or bare soil plots $(F=2.72 ; \mathrm{df}=4,28 ; P=0.05$ ) (Table $3)$. There was no difference in fruit diameter among treatments in 2011 or 2012, indicating that mulch treatments received adequate visitation by

Table 1. Effects of mulch type on soil moisture in study with zucchini squash plants growing in Columbus, $\mathrm{OH}$, in 2011 and in Newark, $\mathrm{OH}$, in 2012. Mulches included no mulch (bare), black plastic, woodchips, shredded newspaper, and shredded newspaper mixed with grass clippings (NP + grass). Data represent means of 35 observations in 2011 and 72 observations in 2012.

\begin{tabular}{lcc}
\hline & \multicolumn{2}{c}{ Volumetric soil water content $\left[\text { mean } \pm \mathrm{SE}\left(\mathbf{m m}^{3} \cdot \mathbf{m m}^{-3}\right)\right]^{\mathrm{z}}$} \\
\cline { 2 - 3 } Mulch type & $\mathbf{2 0 1 1}$ & $\mathbf{2 0 1 2}$ \\
\hline Bare & $25.1 \pm 1.2 \mathrm{~b}^{\mathrm{y}}$ & $10.6 \pm 0.5 \mathrm{c}$ \\
Plastic & $22.4 \pm 1.1 \mathrm{c}$ & $12.7 \pm 0.6 \mathrm{~b}$ \\
Woodchips & $27.6 \pm 1.0 \mathrm{~b}$ & $12.6 \pm 0.5 \mathrm{~b}$ \\
Newspaper & $32.3 \pm 1.2 \mathrm{a}$ & $14.2 \pm 0.5 \mathrm{a}$ \\
NP + grass & $25.3 \pm 1.0 \mathrm{~b}$ & $14.9 \pm 0.6 \mathrm{a}$ \\
\hline
\end{tabular}

${ }^{\mathrm{z}} 1 \mathrm{~mm}^{3}=6.1024 \times 10^{-5}$ inch $^{3}$.

${ }^{y}$ Means \pm SE within a column followed by the same letter are not significantly different according to pairwise $t$ tests with a comparisonwise error rate of alpha $=0.05$

squash bees for full pollination. Plant volume was positively correlated with FYI, and the relationship was stronger in $2012\left(\mathrm{y}=0.22 \mathrm{x}-2.52 ; r^{2}=0.69\right)$ than $2011\left(\mathrm{y}=0.11 \mathrm{x}+64.13 ; r^{2}=\right.$ 0.30) (Fig. 4).

Because the fruit shape data were categorical, the percent of total fruit in each category was analyzed. There were no differences among treatments in percent of misshapen fruit in 2011 . In 2012, a higher percentage of misshapen fruit was produced by plants in plastic and woodchip treatments compared with the bare soil treatment $(F=2.68 ; \mathrm{df}=4,28 ; P=0.05)$ (Table 3). Misshapen fruit included both bulbous and shrunken-end fruit, which may indicate poor pollination or adverse environmental effects on fruit development. There were no differences in the number of aborted fruit among mulch treatments in either year (data not shown).

Floral Resources. There were no differences in male or female squash flower production, pollen grains per male flower, or nectar volume per female flower between plastic, newspaper, and bare soil treatments during the 2012 greenhouse experiment (Table 4). Similarly, in the 2012 field study, there were no differences among treatments in nectar volume of male flowers or in total nectar sugar content of male flowers (Table 4). There were differences in pollen grain number during the 2012 field study, but these were not consistent across
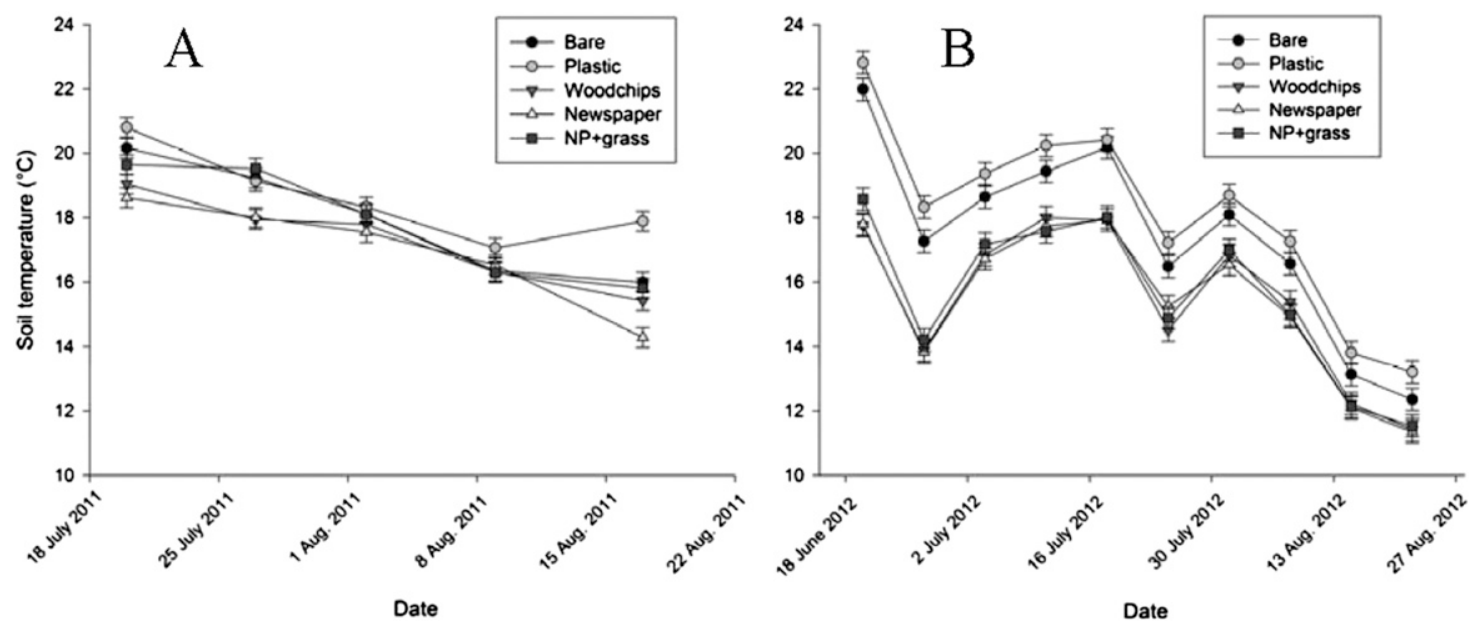

Fig. 3. Average soil temperature from zucchini squash experimental plots at Columbus, $\mathrm{OH}$, in 2011 and Newark, $\mathrm{OH}$, in 2012 , where each line represents a different mulch treatment. Mulches included no mulch (bare), black plastic, woodchips, shredded newspaper, and shredded newspaper mixed with grass clippings (NP + grass); (A) 2011 values during July through August; (B) 2012 values during June through August. Vertical bars represent \pm SE; $\left(1.8 \times{ }^{\circ} \mathrm{C}\right)+32={ }^{\circ} \mathrm{F}$. 
sampling periods. During the first sampling period, newspaper, NP + grass, and bare treatments resulted in more pollen grains per flower than other treatments (Table 5). During the second sampling period, woodchip, plastic, and bare treatments resulted in almost two times more pollen grains per flower than other treatments, and there were no differences among treatments during the third sampling period.

\section{Discussion}

Results indicated there were differential effects of mulch type on pollinator and crop performance and suggest that certain types of mulch

Table 2. Effects of mulch type on zucchini squash plant volume in experiments conducted in Columbus, $\mathrm{OH}$, in 2011 and in Newark, $\mathrm{OH}$, in 2012 measured early and late during the growing season and on average chlorophyll meter SPAD values depicting leaf tissue chlorophyll content in 2012. Mulches included no mulch (bare), black plastic, woodchips, shredded newspaper, and shredded newspaper mixed with grass clippings (NP + grass). Data represent means of 14 observations in 2011 and 16 observations in 2012.

\begin{tabular}{|c|c|c|c|c|c|}
\hline \multirow[b]{2}{*}{ Yr } & \multirow[b]{2}{*}{ Mulch type } & \multicolumn{3}{|c|}{ Volume $\left[\text { mean } \pm \mathrm{SE}\left(\mathrm{dm}^{3} / \text { plant }\right)\right]^{\mathrm{z}}$} & \multirow[b]{2}{*}{ SPAD $^{y}$} \\
\hline & & Early $^{x}$ & Late $^{w}$ & Avg & \\
\hline \multirow[t]{5}{*}{2011} & Bare & $1074 \pm 234$ & $1626 \pm 253$ & $1329 \pm 183 \mathrm{a}^{\mathrm{v}}$ & - \\
\hline & Plastic & $1137 \pm 126$ & $1653 \pm \pm 658$ & $1252 \pm 164 \mathrm{ab}$ & - \\
\hline & Woodchips & $570 \pm 122$ & $1083 \pm 88$ & $775 \pm 114 c$ & - \\
\hline & Newspaper & $769 \pm 113$ & $1161 \pm 242$ & $965 \pm 140 \mathrm{bc}$ & - \\
\hline & $\mathrm{NP}+$ grass & $1309 \pm 79$ & $1908 \pm 145$ & $1534 \pm 128 \mathrm{a}$ & - \\
\hline \multirow[t]{5}{*}{2012} & Bare & $513 \pm 121$ & $957 \pm 221$ & $735 \pm 135 \mathrm{bc}$ & $47.8 \pm 1.4 \mathrm{a}$ \\
\hline & Plastic & $603 \pm 103$ & $1074 \pm 125$ & $838 \pm 99 b$ & $45.7 \pm 1.6 \mathrm{ab}$ \\
\hline & Woodchips & $379 \pm 76$ & $759 \pm 94$ & $569 \pm 76 c$ & $41.6 \pm 1.9 \mathrm{~b}$ \\
\hline & Newspaper & $502 \pm 113$ & $687 \pm 58$ & $595 \pm 66 c$ & $42.8 \pm 1.6 b$ \\
\hline & $\mathrm{NP}+$ grass & $971 \pm 148$ & $1268 \pm 279$ & $1110 \pm 152 a$ & $49.4 \pm 1.4 \mathrm{a}$ \\
\hline
\end{tabular}

${ }^{\mathrm{z}} 1 \mathrm{dm}^{3}=0.0353 \mathrm{ft}^{3}$.

ySPAD values represent leaf chlorophyll content; SPAD meter readings not taken during 2011 season.

xEarly plant volumes were measured at 6 weeks after planting (WAP) in 2011 and 4 WAP in 2012.

"Late plant volumes were measured at 9 WAP in 2011 and 10 WAP in 2012.

${ }^{\mathrm{V}}$ Means $\pm \mathrm{SE}$ within column followed by the same letter are not significantly different according to pairwise $t$ tests with a comparisonwise error rate of alpha $=0.05$.

Table 3. Effects of mulch type on the development of marked zucchini squash fruit $5 \mathrm{~d}$ after bloom, their fruit diameter and the percentage of misshapen fruit during the 2011 and 2012 growing seasons. Mulches included no mulch (bare), black plastic, woodchips, shredded newspaper, and shredded newspaper mixed with grass clippings (NP + grass). Data represent means of seven replications in 2011 and eight replications in 2012. Each plot contained one plant.

\begin{tabular}{llccc}
\hline Yr & Mulch type & $\begin{array}{c}\text { Fruit }[\text { mean } \pm \text { SE } \\
(\text { no. } / \text { plant })]\end{array}$ & $\begin{array}{c}\text { Fruit diam } \\
{[\text { mean } \pm \text { SE }(\mathbf{m m})]^{\mathrm{z}}}\end{array}$ & $\begin{array}{c}\text { Misshapen fruit } \\
{[\text { mean } \pm \text { SE }(\%)]^{\mathrm{y}}}\end{array}$ \\
\hline 2011 & Bare & $3.7 \pm 0.7^{\mathrm{x}}$ & $60.82 \pm 3.25$ & $19.8 \pm 8.5$ \\
& Plastic & $2.6 \pm 0.5$ & $58.44 \pm 3.71$ & $26.2 \pm 7.8$ \\
& Woodchips & $2.7 \pm 0.4$ & $62.87 \pm 2.65$ & $3.6 \pm 3.6$ \\
& Newspaper & $1.9 \pm 0.6$ & $54.66 \pm 2.13$ & $9.5 \pm 9.5$ \\
& NP + grass & $2.8 \pm 0.7$ & $66.68 \pm 4.13$ & $9.5 \pm 6.1$ \\
\multirow{2}{*}{012} & Bare & $2.0 \pm 0.4 \mathrm{~b}^{\mathrm{w}}$ & $36.03 \pm 4.66$ & $3.1 \pm 3.1 \mathrm{~b}$ \\
& Plastic & $3.4 \pm 0.4 \mathrm{a}$ & $45.45 \pm 3.62$ & $45.0 \pm 11.9 \mathrm{a}$ \\
& Woodchips & $2.0 \pm 0.4 \mathrm{~b}$ & $40.83 \pm 3.77$ & $40.6 \pm 14.9 \mathrm{a}$ \\
& Newspaper & $2.0 \pm 0.4 \mathrm{~b}$ & $46.44 \pm 4.72$ & $19.8 \pm 12.4 \mathrm{ab}$ \\
& NP + grass & $3.2 \pm 0.6 \mathrm{a}$ & $48.72 \pm 3.47$ & $27.5 \pm 11.7 \mathrm{ab}$ \\
\hline
\end{tabular}

${ }^{\mathrm{z}} 1 \mathrm{~mm}=0.0394$ inch.

yercent misshapen fruit (includes both shrunken, bulbous, or both).

${ }^{x}$ Columns lacking letters indicate no significant treatment effect.

"Means \pm SE within a column followed by the same letter are not significantly different according to pairwise $t$ tests with a comparisonwise error rate of alpha $=0.05$. may be more conducive to squash bee nesting than others. Three of the mulches tested, woodchips, newspaper, and $\mathrm{NP}+$ grass, had an insulating effect on soil temperature. These mulches resulted in a lower average soil temperature than black plastic or bare soil, indicating that the mulches may have kept the soil beneath them from reaching extreme high temperatures during hot summer days. The lower average soil temperature in combination with higher soil moisture levels observed in woodchip, newspaper, and NP + grass mulch treatments support the first hypothesis that particulate mulch materials would decrease extreme fluctuations in soil temperature and increase soil moisture.

Little is known about factors influencing nest site preference for ground-nesting bee species. Reductions in soil temperature fluctuation and a lower average soil temperature could benefit squash bee development by insulating brood cells and developing larvae from overly high temperatures that could affect development processes. Excessive high temperatures that speed bee development could lead to their premature exit from the soil, making them vulnerable to a late frost or insufficient floral resources (Roulston and Goodell, 2011). Additionally, Julier and Roulston (2009) found a positive effect of irrigation on squash bee nesting, indicating that they prefer to nest in moist soils. On the basis of this finding, it may be that squash bees would prefer to nest under a mulch material that reduces exposure to high temperatures and conserves soil moisture.

No inferences could be made about squash bee nesting preference because we located only four nests, so nesting preference with regard to mulch materials compared with bare soil remains to be investigated. Nests were found in newspaper and NP + grass mulches, so we surmise that these materials did not prohibit nesting. This finding is noteworthy because effective mulches, by design, create a physical barrier to weed emergence that could also inhibit bee nesting (Fig. 5B). In addition, there are differences in color and texture among mulches, which may influence visual cues used by bees to forage or locate nests. Many polyethylene plastic films contain ultraviolet-absorbing 


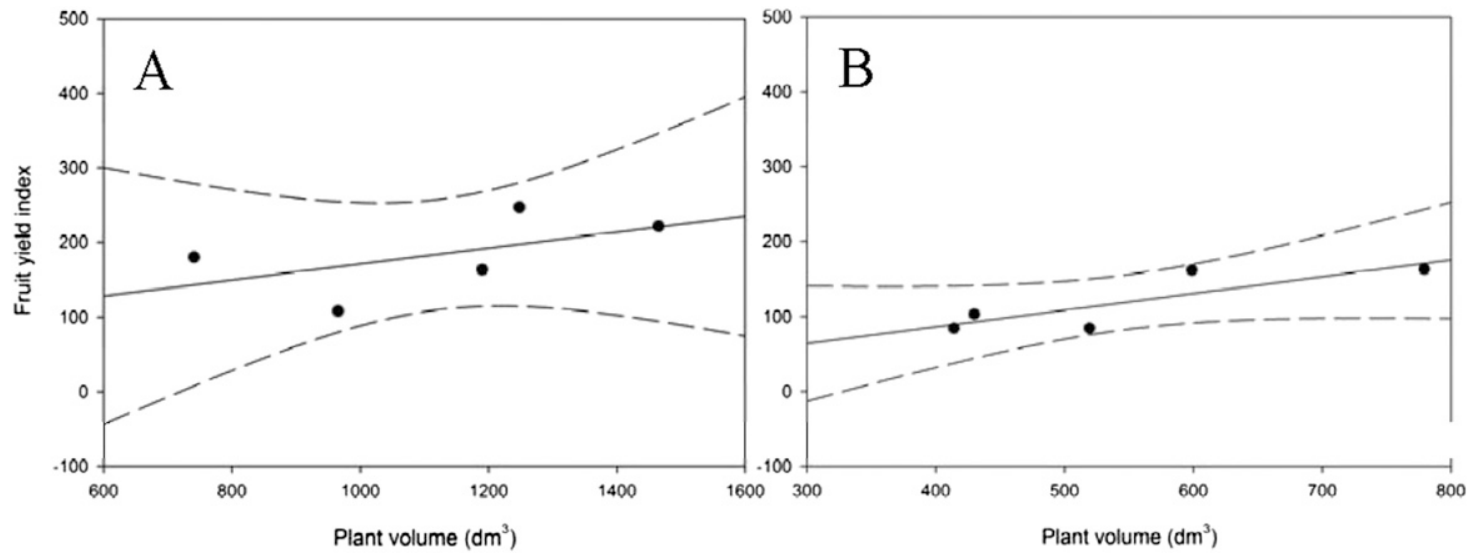

Fig. 4. Relationship between zucchini squash plant volume and fruit yield index $(F Y I=$ fruit number $\times$ fruit diameter) for $(A)$ $2011\left(\mathrm{y}=0.11 \mathrm{x}+64.13, r^{2}=0.30\right)$ and $(\mathrm{B}) 2012\left(\mathrm{y}=0.22 \mathrm{x}-2.52, r^{2}=0.69\right)$. Data points represent treatment means, solid lines represent the linear regression lines, and dashed lines represent $95 \%$ confidence indices. Note that graphs $\mathrm{A}$ and $\mathrm{B}$ have different $\mathrm{X}$-axis scales to accommodate the varying plant volumes reported during 2011 and $2012 ; 1 \mathrm{dm}^{3}=0.0353 \mathrm{ft}^{3}$.

Table 4. Effects of mulch type on zucchini squash (greenhouse) and pumpkin (field) flower production, pollen quantity, and nectar volume and total sugar content (soluble solids) for 2012 greenhouse and field experiments. Mulches included no mulch (bare), black plastic, and newspaper for the greenhouse experiment and no mulch (bare), black plastic, woodchips, shredded newspaper, and shredded newspaper mixed with grass clippings (NP + grass) for the field experiment.

\begin{tabular}{|c|c|c|c|c|c|c|}
\hline Expt. & Mulch type & $\begin{array}{c}\text { Male flowers } \\
{[\text { mean } \pm \text { SE }} \\
(\text { no. } / \text { plant })]\end{array}$ & $\begin{array}{c}\text { Female flowers } \\
{[\text { mean } \pm \text { SE }} \\
(\text { no. } / \text { plant })] \\
\end{array}$ & $\begin{array}{c}\text { Pollen grains } \\
{[\text { mean } \pm \text { SE }} \\
(\text { no. } / \text { flower } \times 100)]\end{array}$ & $\begin{array}{c}\text { Nectar vol } \\
{[\text { mean } \pm \text { SE }} \\
(\mu \mathrm{L} / \text { flower })]^{\mathrm{z}}\end{array}$ & $\begin{array}{c}\text { Soluble solids } \\
{[\text { mean } \pm \text { SE }(\%)]^{\mathrm{y}}}\end{array}$ \\
\hline \multirow[t]{2}{*}{ Greenhouse $^{x}$} & Bare & $18.0 \pm 0.5^{\mathrm{w}}$ & $6.8 \pm 0.4$ & $203.44 \pm 12.54$ & $71.8 \pm 5.89$ & - \\
\hline & Newspaper & $18.2 \pm 0.9$ & $6.5 \pm 0.9$ & $205.30 \pm 12.11$ & $83.9 \pm 9.6$ & - \\
\hline \multirow[t]{4}{*}{ Field $^{v}$} & Bare & $3.4 \pm 0.8$ & $2.0 \pm 0.3$ & - & $81.3 \pm 22.1$ & $34.4 \pm 0.8$ \\
\hline & Woodchips & $3.6 \pm 0.4$ & $2.6 \pm 0.3$ & - & $105.7 \pm 21.2$ & $36.4 \pm 0.7$ \\
\hline & Newspaper & $3.5 \pm 0.5$ & $2.6 \pm 0.5$ & - & $86.5 \pm 28.2$ & $36.5 \pm 1.0$ \\
\hline & $\mathrm{NP}+$ grass & $3.9 \pm 0.4$ & $3.6 \pm 0.6$ & - & $89.1 \pm 15.0$ & $33.5 \pm 2.2$ \\
\hline
\end{tabular}

${ }^{\mathrm{z}} 1 \mu \mathrm{L}=3.3814 \times 10^{-5} \mathrm{fl} \mathrm{oz}$.

y Soluble solids represents the total concentration of all soluble solids in a sample. For floral nectar, this value provides an estimate of percent total sugar content (Corbet 2003 ). ${ }^{x}$ Greenhouse zucchini floral production data presented represent means of 460 observations, pollen data represent means of 60 observations, and nectar data represent means of 10 observations.

${ }^{w}$ Means \pm SE within a column lacking letters indicate no significant treatment effects according to pairwise $t$ tests with a comparisonwise error rate of alpha $=0.05$

${ }^{\vee}$ Field pumpkin floral production data represent means of nine observations, nectar volume and brix percentage data represent means of seven observations.

components to prolong the life of the material, which could influence the flight patterns of insects that use ultraviolet-reflectance patterns as cues for recognizing host plants (Costa et al., 2002). However, it seems more likely that bees would simply be unable or unwilling to pierce the plastic with their mandibles.

Mulches that increased soil moisture did not increase the quantity of nectar produced as we hypothesized. There was also no effect of mulch type on flower number, nectar sugar content, or pollen quantity, indicating that release of plant-available nitrogen, such as what may have occurred with the NP + grass treatment, may have little to no effect on floral resources. Conversely, previous work demonstrated that increasing soil water levels doubled nectar volumes and sucrose content in common and poke milkweed [Asclepias syriaca and A. exaltata (Wyatt et al., 1992)]. Similarly, california fuchsia (Epilobium canum), a hummingbird (Trochilidae)-pollinated herbaceous shrub, produced $\approx 25 \%$ less nectar when grown under low water conditions (Boose, 1997).

Environmental factors, such as soil fertility, impact the ability of a plant to provision its offspring either by altering flower number, pollen production per flower, or both (Delph et al., 1997). Squash pollen produced from plants grown on high phosphorous soil differed in its chemical composition from pollen produced from plants grown on low phosphorus soil (Lau and Stephenson, 1993). Pollen grain size can also differ according to growing conditions (Stephenson et al., 1994). The differences in soil microclimate parameters that resulted from the five mulch treatments tested in this study may not have been sufficient to cause a consistent difference in the floral resources produced by squash, especially since plants were irrigated when needed and received ample fertilizer.

Although larger plants produced higher fruit yields, there were only 
slight differences in total fruit number among mulch treatments, and this effect was inconsistent between years. This effect may be partially attributable to differing weed pressures in 2011 vs. 2012 . Since fruit diameter did not differ consistently among treatments, there was no evidence that pollinator visitation differed among treatments to an extent that influenced fruit quality. Because there were no differences in floral resources among treatments, it is not surprising that there was also no evidence of pollination differences. However, our experimental design may have underestimated the influence of mulches on bee visitation. With our design, overall resource availability was limited to only the flowers in the screenhouse, and bees did not have the option to fly between fields. Additional studies conducted in open field conditions and that measure pollinator visitation would complement our data on pollination.

Higher percentages of misshapen fruit were observed in plots mulched with polyethylene black plastic in 2012 . Since no differences in fruit pollination were observed, environmental factors may have influenced fruit shape. Misshapen fruit may have developed in plastic mulch because of higher soil temperatures in the plant root zone. High root-zone temperatures have been found to reduce water uptake from roots and decrease aboveground biomass (Graves et al., 1991), which might partially explain fruit deformation due to general plant stress.

The most likely cause of misshapen fruit may be the effect of heat stress on pollen tube development. Pollen tubes of squash extended significantly longer when developed in vitro under 20 than $30^{\circ} \mathrm{C}$ (Johansson and Stephenson, 1998). This difference in pollen tube development has been shown to have a direct impact on fruit set resulting in unfertilized ovules at higher temperatures in strawberry [Fragaria Xananassa (Lendesma and Sugiyama, 2005)]. A similar reduction in pollen tube development may be responsible for misshapen zucchini

Table 5. Effects of mulch type on pumpkin pollen quantity in the 2012 field experiment. Mulches included no mulch (bare), black plastic, woodchips, shredded newspaper, and shredded newspaper mixed with grass clippings (NP + grass) for the field experiment. Data represent means of nine observations.

\begin{tabular}{llcc}
\hline & \multicolumn{3}{c}{ Pollen grains [mean \pm SE $($ no./flower $\times$ 100 $)]$} \\
\cline { 2 - 4 } Mulch type & \multicolumn{1}{c}{ 24 July 2012 } & 7 Aug. 2012 & 20 Aug. 2012 \\
\hline Bare & $310.92 \pm 38.53 \mathrm{ab}^{\mathrm{z}}$ & $446.25 \pm 44.98 \mathrm{a}$ & $257.83 \pm 14.24$ \\
Plastic & $274.17 \pm 92.37 \mathrm{~b}$ & $479.79 \pm 30.75 \mathrm{a}$ & $218.46 \pm 5.86$ \\
Woodchips & $227.79 \pm 59.16 \mathrm{~b}$ & $517.71 \pm 46.11 \mathrm{a}$ & $245.00 \pm 37.15$ \\
Newspaper & $417.67 \pm 73.09 \mathrm{a}$ & $292.25 \pm 37.01 \mathrm{~b}$ & $209.71 \pm 25.25$ \\
NP + grass & $399.88 \pm 43.30 \mathrm{a}$ & $254.25 \pm 54.72 \mathrm{~b}$ & $249.38 \pm 7.44$ \\
\hline
\end{tabular}

${ }^{2}$ Means \pm SE within a column followed by the same letter are not significantly different according to pairwise $t$ tests with a comparisonwise error rate of alpha $=0.05$. Columns lacking letters indicate no significant treatment effect.

fruits found in black plastic. Ambient air temperatures reached well over $30{ }^{\circ} \mathrm{C}$ during both years of the study (Fig. 2) and air temperatures in areas where soil was covered with black plastic were likely hotter than other treatment areas because of the heat absorption properties of black plastic.

The NP + grass mulch resulted in plants with higher apparent leaf chlorophyll content than other treatments, suggesting the addition of plant-available nitrogen. Plant volume was also greater in NP + grass mulch and total fruit numbers were greater in 2012. This mulch also allowed for squash bee nesting and conserved soil moisture while decreasing extreme soil temperatures, which may be beneficial to squash bee and squash performance. On the basis of our findings, shredded newspaper mulch when combined with grass clippings has potential for use in squash plantings to conserve native pollinator populations and improve crop performance.

In summary, further research is needed to determine nesting preferences specific to squash bees regarding mulch type. Squash bees may prefer to nest under a particular mulch material rather than bare soil due to mulch's effects on the soil microclimate. The effect of mulch on crop pollination and fruit production of zucchini should also be investigated further to determine the exact mechanism causing misshapen fruit. The impact of mulch materials on soil microclimate and on the microclimate directly surrounding crop plants may have a greater impact on fruit

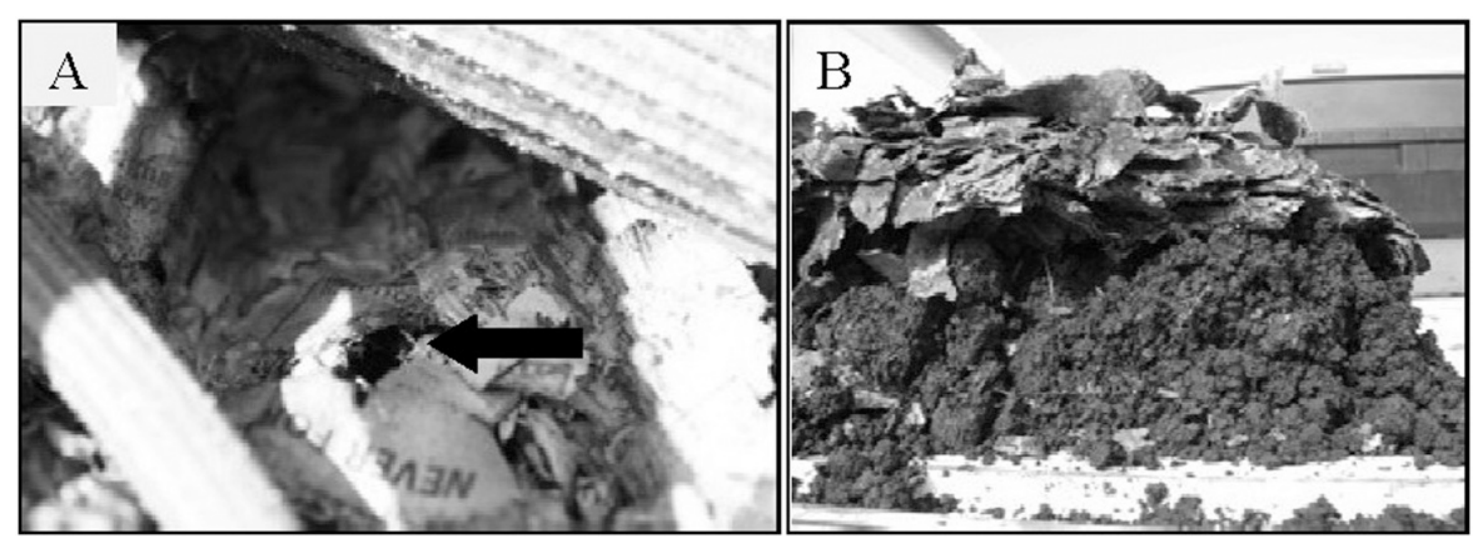

Fig. 5. (A) Image of squash bee nest site located within newspaper and grass mulch. Arrow points to nest entrance. (B) Image of cross section of newspaper mulch at the surface of the soil, indicating the physical barrier of the mulch to weed emergence and to squash bee nest excavation. 
shape than on pollinator visitation, which did not differ among the mulch treatments studied. To better understand how mulches may influence floral resource production, effects of mulch should be determined under varying water and nutrient stress conditions to see if certain mulch materials are able to buffer the environmental factors that cause decreases in the quantity and/or quality of nectar and pollen. The potential benefits of such research include increasing marketable fruit and vegetable crop yields, reducing costs for farmers, and increasing sustainability within local food systems.

\section{Literature cited}

Boose, D.L. 1997. Sources of variation in floral nectar production rate in Epilobium canum (Onagraceae): Implications for natural selection. Oecologia 110:493500 .

Cane, J.H., B.J. Sampson, and S.A. Miller. 2011. Pollination value of male bees: The specialist bee Peponapis pruinosa (Apidae) at summer squash (Cucurbita реро). Environ. Entomol. 40:614-620.

Chauhan, B.S., R.G. Singh, and G. Mahajan. 2012. Ecology and management of weeds under conservation agriculture: A review. Crop Protection 38:56-65.

Corbet, S.A. 2003. Nectar sugar content: Estimating standing crop and secretion rate in the field. Apidologie (Celle) 34:1-10.

Costa, H.S., K.L. Robb, and C.A. Wilen. 2002. Field trials measuring the effects of ultraviolet-absorbing greenhouse plastic films on insect populations. J. Econ. Entomol. 95:113120.

Cruden, R.W., S.M. Hermann, and S. Peterson. 1983. Patterns of nectar production and plant animal coevolution, p. 126-152. In: B. Bentley and T. Elias (eds.). The biology of nectaries. Columbia Univ. Press, New York, NY.

Das Gracas Vidal, M., D. De Jong, H.C. Wien, and R.A. Morse. 2006. Nectar and pollen production in pumpkin (Cucurbita pepo L.). Revista Brasileira de Botanica 29:267-273.

Delaplane, K.S. and D.F. Mayer. 2000. Crop pollination by bees. CABI Publ., New York, NY.

Delph, L.F., M.H. Johannsson, and A.G. Stephenson. 1997. How environmental factors affect pollen performance: Ecological and evolutionary. Ecology 78:16321639.
Fahn, A. 1979. Secretory tissues in plants. Academic Press, London, UK.

Gianessi, L.P. and N.P. Reigner. 2007 The value of herbicides in U.S. crop production. Weed Technol. 21:559-566.

Gomez, K.A. and A.A. Gomez. 1984. Statistical procedures in agricultural research. Wiley, New York, NY.

Graves, W.R., R.J. Joly, and M.N. Dana. 1991. Water use and growth of honey locust and tree-of-heaven at high rootzone temperature. HortScience 26:13091312.

Hobbs, P.R., K. Sayre, and R.K. Gupta. 2008. The role of conservation agriculture in sustainable agriculture. Philos. Trans. R. Soc. Lond., B 363:543-555.

Holzschuh, A., I. Steffan-Dewente, and T. Tscharntke. 2008. Agricultural landscapes with organic crops support higher pollinator diversity. Oikos 117:354361.

Hurd, P.D. Jr., E.G. Linsley, and A.E. Michelbacher. 1974. Ecology of the squash and gourd bee, Peponapis pruinosa, on cultivated cucurbits in California (Hymenoptera: Apoidea). Smithson. Contrib. Zool. 168:1-17.

Johansson, M.H. and A.G. Stephenson. 1998. Effects of temperature during microsporogenesis on pollen performance in Cucurbita pepo L. (Cucurbitaceae). Intl. J. Plant Sci. 159:616-626.

Julier, H.E. and T.H. Roulston. 2009. Wild bee abundance and pollination service in cultivated pumpkins: Farm management, nesting behavior and landscape effects. J. Econ. Entomol. 201: 563-573.

Lau, T.C. and A.G. Stephenson. 1993. Effects of soil nitrogen on pollen production, pollen grain size, and pollen performance in Cucurbita pepo (Cucurbitaceae). Amer. J. Bot. 80:763-780.

Lendesma, N. and N. Sugiyama. 2005. Pollen quality and performance in strawberry plants exposed to high temperature stress. J. Amer. Soc. Hort. Sci. 130:341-347.

Liebman, M. 2001. Weed management: A need for ecological approaches, p. 1-39. In: M. Liebman, C.L. Mohler, and C.P. Staver (eds.). Ecological management of agricultural weeds. Cambridge Univ. Press, New York, NY.

Littell, R.C., G.A. Milliken, W.W. Stroup, R.D. Wolfinger, and O. Schabenberger. 2006. SAS for mixed models. 2 nd ed. SAS Institute, Cary, NC.
Mathewson, J.A. 1968. Nest construction and life history of the eastern cucurbit bee, Peponapis pruinosa (Hymenoptera: Apoidea). J. Kans. Entomol. Soc. 41:255-261.

Nepi, M., M. Guarnieri, and E. Pacini. 2001. Nectar secretion, readsorption, and sugar composition in male and female flowers of Cucurbita pepo. Intl. J. Plant Sci. 162:353-358.

Nepi, M., E. Pacini, and M.T.M. Willemse. 1996. Nectary biology of Cucurbita pepo: Ecophysiological aspects. Acta Botanica Neerlandica 45:41-54.

Powles, S.B. and Q. Yu. 2010. Evolution in action: Plants resistant to herbicides. Annu. Rev. Plant Biol. 61:317-347.

Rawal, A., D. Moyo, V. Soukupova, and R. Anandjiwala. 2007. Optimization of parameters in hydroentanglement process. J. Ind. Textiles 36:207-220.

Roulston, T.H., J.H. Cane, and S.L. Buchmann. 2000. What governs protein content of pollen: Pollinator preferences, pollen-pistil interactions, or phylogeny? Ecol. Monogr. 70:617-643.

Roulston, T.H. and K. Goodell. 2011. The role of resources and risks in regulating wild bee populations. Annu. Rev. Entomol. 56:293-312.

Shaw, N.L. and D.J. Cantliffe. 2005. Hydroponic greenhouse production of "baby" squash: Selection of suitable squash types and cultivars. HortTechnology 15:722-728.

Splawski, C.E. 2012. Mulch effects on squash (Cucurbita pepo L.) and pollinator (Peponapis pruinosa Say.) performance. Ohio State Univ., Columbus, MS Thesis.

Stephenson, A.G., C.W. Erickson, T.C. Lau, M.R. Quesada, and J.A. Winsor. 1994. Pollen-pistil interactions and pollen tube growth: Effects of growing conditions on the male gametophyte, p. 220229. In: A.G. Stephenson and T.H. Kao (eds.). Current topics in plant physiology. Vol. 12. Amer. Soc. Plant Physiologists, Rockville, MD.

Tepedino, V.J. 1981. The pollination efficiency of the squash bee (Peponapis pruinosa) and the honey bee (Apis mellifera) on summer squash (Cucurbita pepo). J. Kans. Entomol. Soc. 54:359-377.

Walters, S.A. and B.H. Taylor. 2006. Effects of honeybee pollination on pumpkin fruit and seed yield. HortScience $41: 370-373$.

Williams, R., D. Fickle, A. Michel, and K. Goodell. 2009. Pumpkin pollinator: Biology and behavior of the squash bee, Peponapis pruinosa (Say). Agr. Natural 
Resources, Ohio State Univ. Ext., Fact Sheet CV-1003-09. 12 Dec. 2011. $<$ http://ohioline.osu.edu/cv-fact/ pdf/1003.pdf>.
Wyatt, R., S.B. Broyles, and G.S. Derda. 1992. Environmental influences on nectar production in milkweeds (Asclepias siriaca and $A$. exaltata). Amer. J. Bot. 79:636-642.
Xiang, P. and A.V. Kuznetsov. 2008. Simulation of shape dynamics of a long flexible fiber in a turbulent flow in the hydroentanglement process. Intl. Commun. Heat Mass 35:529-534. 